\title{
MENINGKATKAN PRESTASI BELAJAR SISWA KELAS XII IPA 1 PADA PELAJARAN KIMIA MATERI SEL ELEKTROKIMIA SMA NEGERI 1 KAYUAGUNG MELALUI STRATEGI PEMBELAJARAN KONSTRUKTIVISME
}

\author{
Usinawati \\ Guru SMA Negeri 1 Kayuagung \\ usinawati@gmail.com
}

\begin{abstract}
ABSTRAK
Penelitian tindakan kelas ini berjudul "Meningkatkan Prestasi Belajar Siswa Kelas XII IPA 1 Pada Pelajaran Kimia Materi Sel Elektrokimia SMA Negeri 1 Kayuagung Melalui Strategi Pembelajaran Konstruktivisme.Penelitian ini bertujuan untuk mengetahui peningkatan hasil belajar siswa kelas XII IPA 1 SMA Negeri 1 Kayuagung setelah diterapkannya Strategi Pembelajaran Konstruktivisme sehingga pembelajaran Kimia menjadi lebih menyenangkan dan menimbulkan kreatifitas siswa. Rumusan masalah adalah bagaimana penerapan Strategi Pembelajaran Konstruktivisme sehingga dapat meningkatkan hasil belajar Kimia siswa kelas XII IPA 1 SMA Negeri 1 Kayuagung?. Penelitian ini menggunakan penelitian tindakan kelas sebanyak dua putaran. Setiap putaran terdiri dari empat tahap yaitu: rancangan, kegiatan dan pengamatan, refleksi, dan refisi. Sasaran penelitian ini adalah siswa kelas XII IPA 1 SMA Negeri 1 Kayuagung. Data yang diperoleh berupa hasil tes formatif. Dari hasil analis didapatkan bahwa rata rata hasil belajar siswa mengalami peningkatan dari pra siklus 64,53, siklus I 68,53 dan siklus II 81,17. Jadi kesimpulan dari penelitian ini adalah Strategi Pembelajaran Konstruktivisme dapat berpengaruh positif terhadap hasil belajar siswa kelas XII IPA 1 SMA Negeri 1 Kayuagung.
\end{abstract}

Kata Kunci: Kimia, Strategi Pembelajaran Konstruktivisme, Prestasi Belajar

\section{ABSTRACT}

This classroom action research entitled "Improving Student Achievement in Class XII IPA 1 in Chemistry Lessons on Electrochemical Cell Material at SMA Negeri 1 Kayuagung through Constructivism Learning Strategies. This research aims to determine the increase in student learning outcomes of class XII IPA 1 SMA Negeri 1 Kayuagung after the implementation of the Learning Strategy. Constructivism so that learning Chemistry becomes more fun and raises student creativity. The 
formulation of the problem is how to implement the Constructivism Learning Strategy so that it can improve the learning outcomes of Chemistry class XII IPA 1 students of SMA Negeri 1 Kayuagung ?. This study uses two rounds of classroom action research. Each cycle consists of four stages, namely: design, activity and observation, reflection, and revision. The target of this research is students of class XII IPA 1 SMA Negeri 1 Kayuagung. The data obtained are in the form of formative test results. From the results of the analysis, it was found that the average student learning outcomes increased from pre-cycle 64.53, cycle I 68.53 and cycle II 81.17. So the conclusion of this study is that the constructivism learning strategy can have a positive effect on the learning outcomes of students in class XII IPA 1 SMA Negeri 1 Kayuagung.

Keywords: Chemistry, Constructivism Learning Strategy, Learning Achievement

\section{PENDAHULUAN}

Sekolah adalah tempat bagi setiap peserta didik untuk belajar dan menuntut ilmu pengetahuan. Sekolah harus mampu berfungsi secara optimal sebagai tempat terjadi nya proses belajar-mengajar antara guru dan peserta didik, dengan demikian sekolah dapat mewujudkan tujuan dari pendidikan nasional yang berfungsi mencerdaskan kehidupan bangsa dan memajukan kebudayaan nasional. Peningkatan kualitas pembelajaran merupakan salah satu peningkatan mutu pendidikan secara keseluruhan. Upaya peningkatan mutu pendidikan adalah bagian terpadu dari upaya peningkatan kualitas manusia, baik aspek kemampuan, kepribadian maupun tanggung jawab sebagai warga negara (Sutama, 2000:3). Marsigit (dalam Sutama, 2000:1), menyatakan bahwa ahli-ahli kependidikan telah menyadari mutu pendidikan sangat tergantung pada kualitas guru dan kualitas pembelajarannya, sehingga peningkatan kualitas pembelajaran merupakan isi dasar bagipeningkatan mutu pendidikan secara nasional. Menurut Anies (dalam Asmani 2011: 37-39), proses pendidikan saat ini diibaratkan terlalu mementingkan 
aspek kognitif dan mengabaikan kreativitas.

Pada pembelajaran Kimia, materi tentang Sel Elektrokimia baru disampaikan pada jenjang Sekolah Menengah Atas. Sel Elektrokimia adalah suatu alat yang menghasilkan arus listrik dari energi yang dihasilkan oleh reaksi di dalam selnya, yaitu reaksioksidasi dan reaksi reduksi (reaksiredoks). Sel Elektrokimia tersusun dari dua material penghantar atau konduktor listrik yang disebut dengan katoda dan anoda. Pemahaman tepat yang disampaikan guru akan mempermudah siswa dalam mencapai Kriteria Ketuntasan Minimal (KKM) yang telah ditetapkan sekolah.

Salah satu kompetensi dasar yang diusung dalam kurikulum 2013 untuk Sekolah Menengah Atas (SMA) adalah tentang pemahaman mengenai konsep Sel Elektrokimia pada mata pelajaran Kimia. Namun kenyataan menunjukkan bahwa, kemampuan pemahaman akan konsep Sel Elektrokimia siswa belum memadai. Hal tersebut terlihat pada pembelajaran Sel Elektrokimia di SMA Negeri 1 Kayuagung. Hasil pembelajaran siswa pada materi Sel Elektrokimia SMA Negeri 1 Kayuagung tergolong masih rendah, khususnya di kelasXII IPA 1. Selain itu, jumlah siswa yang berhasil mencapai dan melampaui KKM masih kurang dari $75 \%$.

Berdasarkan pengamatan awal penelitian, rendahnya hasil pembelajaran Sel Elektro kimia siswa kelas XII IPA 1 SMA Negeri 1 Kayuagung terlihat dari hasil pembelajaran Set Elektro kimia siswa yang belum mengenai sasaran. Kegiatan pembelajaran yang tidak bervariasi kurang mendapat respon positif dari siswa yang sedang berada dalam tataran usia remaja. Oleh karena itu, pada usia ini anak membutuhkan teknik pembelajaran yang bervariasi.

Berdasarkan latar belakang masalah di atas, melalui penelitian ini akan diterapkan strategi pembelajaran Konstruktivisme untuk meningkatkan kemampuan siswa pada materi Sel Elektro kimia siswa kelas XII IPA 1 SMA Negeri 1Kayuagung. Melalui strategi pembelajaran Konstruktivisme ini diharapkan dapat meningkatkan kemampuan siswa dalam mempelajari materi Sel Elektrokimia. Dan judul 
pada penelitian ini adalah: "Meningkatkan Prestasi Belajar Siswa Kelas XII IPA 1Pada Pelajaran Kimia Materi Sel Elektro kimia SMA Negeri 1 Kayuagung Melalui Strategi Pembelajaran Konstruktivisme Tahun Pelajaran 2019/2020".Rumusan masalah dalam penelitian ini adalah bagaimana upaya yang harus dilakukan dalam meningkatkan prestasi belajar siswa pada materi Sel Elektro kimia melalui penerapan strategi pembelajaran Konstruktivisme siswa kelas XII IPA 1 SMA Negeri 1 Kayuagung?.Tujuan pada penelitian ini adalah untuk dapat meningkatkan pretasi belajar siswa pada materi Sel Elektro kimia kelas XII IPA 1 SMA Negeri 1 Kayuagung tahun pelajaran 2019/2020 dengan menggunakan strategi pembelajaran Konstruktivisme.

\section{LANDASAN TEORI}

Prestasi belajar adalah sesuatu yang dapat dicapai yang dinampakkan dalam pengetahuan, sikap, dan keahlian. Prestasi tidak akan pernah dihasilkan selama seseorang jika tidak melakukan suatu kegiatan. Untuk mendapatkan prestasi dibutuhkan keuletan dan kegigihan kerja. Menurut
Hamdani (2011:137) prestasi yaitu hasil dari suatu kegiatan yang telahdi kerjakan, diciptkan baik secara individual maupun kelompok. Sedangkan menurut Syaiful Bahri Djamarah (2012:21) prestasi yaitu hasil dari suatu kegiatan yang telah dikerjakan, diciptakan, yang menyenangkan hati yang diperoleh dengan jalan keuletan kerja, baik secara individual maupun kelompok dalam bidang kegiatan tertentu.

Menurut Dharma Kesuma dkk (2012:21) belajar yaitu suatu pengalaman yang mendahului perubahan perilaku seseorang. Sedangkan menurut Nana Sudjana (2010:5) belajar adalah suatu proses yang ditandai dengan adanya perubahan pada diri seseorang. Perubahan tersebut dapat ditunjukan dalam berbagai bentuk seperti perubahan pengetahuan, pemahaman, sikap, dan tingkah laku, keterampilan, kecakapan, kebiasaan, serta perubahan aspek-aspek lain yang ada pada individu yang belajar. Hal tersebut sejalan dengan pendapat Slameto (2013:2) belajar adalah suatu proses usaha yang dilakukan seseorang untuk 
memperoleh suatu perubahan tingkah laku yang baru secara keseluruhan, sebagai hasil pengalaman sendiri dalam interaksi dan lingkungannya.

Menurut Sardiman (2011:46) prestasi belajar merupakan kemampuan nyata yang merupakan hasil interaksi antara berbagai faktor yang mempengaruhi baik dari dalam maupun dari luar dari individu dalam belajar. Sedangkan Syaiful Bahri Djamarah (2012:23) prestasi belajar yaitu hasil yang diperoleh berupa kesan-kesan yang mengakibatkan perubahan dalam diri individu sebagai hasil dari aktivitas dalam belajar. Hal tersebut sejalan dengan pendapat Hamdani (2011:138) yang mengatakan bahwa prestasi belajar yaitu hasil yang diperoleh berupa kesan-kesan yang mengakibatkan perubahan dalam diri individu sebagai hasil dari sebuah aktivitas. Prestasi belajar merupakan tingkatan sejauh mana siswa dapat mencapai tujuan yang sudah ditetapkan.

Pada hakikat nya belajar dan pembelajaran adalah suatu kegiatan yang tidak dapat terpisahkan dari kehidupan manusia, dengan belajar manusia dapat mengembangkan potensi-potensi yang dimilikinya. Aktualisasi potensi amat berguna bagi manusia untuk dapat menyesuaikan diri demi pemenuhan kebutuhannya. Belajar (Slameto, 2003:2) adalah suatu proses, usaha yang dilakukan seseorang untuk memperoleh suatu perubahan tingkah laku yang baru secara keseluruhan, sebagai hasil pengalamannya sendiri dalam interaksi dengan lingkungannya.

Sedangkan belajar menurut W.S Winkel (2004:59) yaitu suatu aktivitas mental atau psikis yang berlangsung dalam interaksi aktif dengan lingkungan, yang menghasilkan perubahan dalam pengetahuan,

pemahaman,keterampilan, dan nilai sikap. Hasil dari belajar tidak hanya sekedar perubahan tingkah laku namun juga perubahan dalam pengetahuan, pemahaman,keterampilan, dan nilai sikap.

Menurut Oemar Hamalik (2008:57) pembelajaran adalah suatu kombinasi yang tersusun dari manusia, material, fasilitas, perlengkapan, dan prosedur, yang saling mempengaruhi 
dalam mencapai tujuan pembelajaran.Sedangkan pembelajaran kimia merupakan suatu upaya guru dalam menyampaikan ilmu kimia serta penerapannya dalam kehidupan seharihari.Dalam kegiatan pembelajaran kimia dibutuhkan strategi, metode, teknik maupun model pembelajaran sehingga tujuan pembelajaran kimia dapat tercapai dengan optimal. Strategi pembelajaran merupakan cara-cara yang digunakan oleh guru untuk memilih kegiatan belajar yang akan digunakan selama proses pembelajaran.

Teori Konstruktivisme didefinisikan sebagai pembelajaran yang bersifat generatif, yaitu tindakan mencipta sesuatu makna dari apa yang dipelajari. Konstruktivisme sebenarnya bukan merupakan gagasan yang baru, apa yang di lalui dalam kehidupan kita selama ini merupakan himpunan dan pembinaan pengalaman demi pengalaman. Ini menyebabkan seseorang mempunyai pengetahuan dan menjadi lebih dinamis. Pendekatan Konstruktivisme mempunyai beberapa konsep umum seperti:
1) Pelajar aktif membina pengetahuan berasaskan pengalaman yang sudah ada.

2) Dalam konteks pembelajaran, pelajar seharusnya membina sendiri pengetahuan mereka.

3) Pentingnya membina pengetahuan secara aktif oleh pelajar sendiri melalui proses saling memengaruhi antara pembelajaran terdahulu dengan pembelajaran terbaru.

4) Unsur terpenting dalam teori ini ialah seseorang membina pengetahuan dirinya secara aktif dengan cara membandingkan informasi baru dengan pemahamannya yang sudah ada.

5) Ketidak seimbangan merupakan factor motivasi pembelajaran yang utama. Faktor ini berlaku apabila seorang pelajar menyadari gagasan-gagasannya tidak konsisten atau sesuai dengan pengetahuan ilmiah.

6) Bahan pengajaran yang disediakan perlu mempunyai perkaitan dengan pengalaman 
pelajar untuk menarik minat pelajar.

Teori

Konstruktivisme

didefinisikan sebagai pembelajaran yang bersifat generatif, yaitu tindakan mencipta sesuatu makna dari apa yang dipelajari. Beda dengan aliran behavioristik yang memahami hakikat belajar sebagai kegiatan yang bersifat mekanistik antara stimulus respon, kontruktivisme lebih memahami belajar sebagai kegiatan manusia membangun atau menciptakan pengetahuan dengan member makna pada pengetahuan nya sesuai dengan pengalamanya.

Konstruktivisme sebenarnya bukan merupakan gagasan yang baru, apa yang dilalui dalam kehidupan kita selama ini merupakan himpunan dan pembinaan pengalaman demi pengalaman. Ini menyebabkan seseorang mempunyai pengetahuan dan menjadi lebih dinamis.

Menurut teori ini, satu prinsip yang mendasar adalah guru tidak hanya memberikan pengetahuan kepada siswa, namun siswa juga harus berperan aktif membangun sendiri pengetahuan di dalam memorinya. Dalam hal ini, guru dapat memberikan kemudahan untuk proses ini, dengan membri kesempatan kepada siswa untuk menemukan atau menerapkan ide - ide mereka sendiri, dan mengajar siswa menjadi sadar dan secara sadar menggunakan strategi mereka sendiri untuk belajar. Guru dapat memberikan siswa anak tangga yang membawa siswa ketingkat pemahaman yang lebih tinggi dengan catatan siswa sendiri yang mereka tulis dengan bahasa dan kata - kata mereka sendiri.

\section{METODE PENELITIAN}

Penelitian ini termasuk jenis penelitian tindakan kelas (PTK). Penelitian Tindakan Kelas adalah salah satu jenis penelitian tindakan yang dilakukan guru untuk meningkatkan kualitas pembelajaran di kelasnya (Pardjono dkk, 2007:12). Jenis penelitian ini digunakan dengan alas an peneliti dapat mengamati peningkatan kemampuan siswa, meliputi proses dan hasil pembelajaran, dengan diterapkannya strategi Konstruktivisme. Penelitian ini melibatkan Guru sebagai peneliti yang berkolaborasi dengan guru mapel Kimia SMA Negeri 1 Kayuagung. 
Dari hasil observasi awal yang dilakukan peneliti dapat diketahui bahwa pembelajaran Sel Elektro kimia belum pernah dilakukan menggunakan strategi Konstruktivisme. Berdasarkan keadaan tersebut, penelitian dengan strategi Konstruktivisme diharapkan dapat membantu siswa untuk menciptakan sebuah konsep belajar Sel Elektrokimia yang baik sekaligus dapat meningkatkan apresiasi terhadap pembelajaran Kimia khususnya pada materi Sel Elektrokimia. Desain penelitian tindakan kelas diawali dengan perencanaan tindakan (planning), tindakan (action), observasi (observe,) dan refleksi (reflect).

Tempat penelitian dilaksanakan di SMA Negeri 1 Kayuagung yang berlokasi di Jalan Muchtar Saleh No 7, Kayuagung, Paku, Kecamatan Kayuagung Kabupaten Ogan Komering Ilir, Sumatera Selatan Komering Ilir. Subjek yang menerima tindakan adalah siswa kelas XII IPA 1 yang berjumlah 30 siswa. Dipilihnya sekolah ini sebagai tempat meneliti karena peneliti adalah sebagai guru mata pelajaran Kimia di SMA Negeri
1 Kayuagung tersebut . Penelitian tindakan kelas ini dilaksanakan pada 2 September 2019 sampai 3 November 2019. Adapun pelaksanaan tindakan sesuai dengan jadwal pelajaran serta silabus yang sesuai dengan kurikulum 2013 mengenai Sel Elektrokimia yang terdapat di kelas XII semester 1. Setiap minggunya pelajaran Kimia disampaikan 4 jam. Khusus di kelas XII IPA 1 pembelajaran Kimia berlangsung setiap Senin dan Rabu. Senin jam ke-1 dan ke-2 yaitu pukul 07.00 WIB sampai 08.30. Rabu jam ke-7 dan jam ke-8 yaitu pukul 12.00 WIB sampai 13.30 WIB. Prosedur penelitian tindakan kelasdapat dilaksanakan melalui empat langkah utama yaitu perencanaan, tindakan, observasi, dan refleksi. Empat langkah utama yang saling berkaitan itu dalam pelaksanaan penelitian tindakan kelas sering disebut dengan istilah satu siklus.

\section{HASIL DAN PEMBAHASAN}

\section{Siklus 1}

Perencanaan penelitian tindakan kelas siklus 1 ini dirancang oleh peneliti. Perencanaan disusun bertujuan merencanakan pelaksanaan 
tindakan untuk meningkatkan pemahaman siswa pada materi Sel Elektrokimia. Setelah dilakukan tes awal materi Sel Elektro kimia diketahui skor rata-rata kemampuan siswa sebesar 60,35. Skor rata-rata tersebut tentu masih di bawah Kriteria Ketuntasan Minimal (KKM) pelajaran Kimia, yaitu 75 dan masih di bawah kriteria keberhasilan penelitian, yakni lebih dari atau sama dengan 75 . Berdasarkan hasil yang ada, peneliti dan kolaborator memutuskan untuk menggunakan media kartonstruktur berbantu kata krisis yang sudah ditentukan.

Pada saat pelaksanaan kegiatan menggunakan strategi Konstruktivisme,siswa terlihat lebih bersemangat. Meskipun masih ada siswa yang ramai, tetapi suasana masih kondusif. Hal-hal yang diamati dari situasi kegiatan belajar siswa terbagi menjadi dua bagian, yaitu verbal dan nonverbal. Verbal meliputi aktivitas siswa secara lisan sedangkan nonverbal meliputi aktivitas siswa secara tindakan. Sementaraitu, hal yang diamati dari peran guru adalah penguasaan materi dan kelas, pelaksanaan Sel Elektrokimia menggunakan strategi Konstruktivisme, alokasi waktu, pembimbingan terhadap siswa, penguasaan media dengan strategi, kejelasan penugasan, pengevaluasian hasil kerja siswa dan pemantauan. Keberhasilan proses siklus 1 dilaksanakan dengan tiga kali pertemuan. Pada pertemuan pertama pembelajaran di siklus I, masih terdapat beberapa siswa yang menyahut asal-asalan pertanyaan guru, tidak menjawab pertanyaan saat ditunjuk, dan siswa kurang memperhatikan pelajaran. Aktivitas siswa pada awal tindakan pembelajaran cenderung pasif. Hal initerbukti dari table pengamatan berikut.

Tabel Hasil Observasi pada Siklus 1

\begin{tabular}{|c|c|c|c|c|c|}
\hline \multirow{2}{*}{$\begin{array}{l}\mathbf{N} \\
\mathbf{O}\end{array}$} & \multirow{2}{*}{ ASPEK } & \multirow{2}{*}{ INDIKATOR } & \multicolumn{3}{|c|}{$\begin{array}{l}\text { PERTEM } \\
\text { UAN KE - }\end{array}$} \\
\hline & & & 1 & 2 & 3 \\
\hline 1 & $\begin{array}{l}\text { Situasi } \\
\text { Belajar }\end{array}$ & $\begin{array}{l}\text { Keantusiasansiswamengi } \\
\text { kuti proses pembelajaran }\end{array}$ & $\begin{array}{l}4 \\
8 \\
\%\end{array}$ & $\begin{array}{l}5 \\
0 \\
\%\end{array}$ & $\begin{array}{l}6 \\
5 \\
\%\end{array}$ \\
\hline 2 & $\begin{array}{l}\text { Perhatian/ } \\
\text { Fokus }\end{array}$ & $\begin{array}{l}\text { Perhatiansiswaterhadapp } \\
\text { enjelasan guru saat } \\
\text { proses pembelajaran }\end{array}$ & $\begin{array}{l}4 \\
5 \\
\%\end{array}$ & $\begin{array}{l}5 \\
0 \\
\%\end{array}$ & $\begin{array}{l}6 \\
0 \\
\%\end{array}$ \\
\hline 3 & Keaktifan & $\begin{array}{l}\text { Peransiswadalam proses } \\
\text { pembelajaran }\end{array}$ & $\begin{array}{l}4 \\
0 \\
\% \\
\end{array}$ & $\begin{array}{l}5 \\
0 \\
\% \\
\end{array}$ & $\begin{array}{l}6 \\
5 \\
\%\end{array}$ \\
\hline 4 & $\begin{array}{l}\text { Proses } \\
\text { Belajar }\end{array}$ & $\begin{array}{l}\text { Susasana proses } \\
\text { pembelajaran di kelas }\end{array}$ & $\begin{array}{l}4 \\
5 \\
\% \\
\end{array}$ & $\begin{array}{l}5 \\
0 \\
\% \\
\end{array}$ & $\begin{array}{l}6 \\
0 \\
\% \\
\end{array}$ \\
\hline
\end{tabular}


Keterangan:

BS : BaikSekali (76\%-100\%)

B :Baik (51\%-75\%)

C : Cukup (26\%-50\%)

$\mathrm{K}$ : Kurang (0\%-25\%)

Saat memasuki tahap pembelajaran materi Sel Elektrokimia pada siklus 1, siswa sudah menunjukkan peningkatan dalam hal kegiatan siswa selama proses pembelajaran materi Sel Elektrokimia. Berdasarkan pengamatan aspek situasi belajar mengalami peningkatan sebesar $17 \%$ dari pertemuan 1 dan 3 . Perhatian siswa meningkat $15 \%$, dari $45 \%$ menjadi $60 \%$. Siswa juga sudah mulai aktif dalam pembelajaran, terbukti meningkat $25 \%$ dari pertemuan 1 kepertemuan 3. Suasana belajar mengajar sudah mulai kondusif, meningkat $15 \%$.

Saat siswa diinstruksikan untuk Sel Elektro kimia siswa mulai merasa kurang antusias. Namun, setelah guru menentukan permasalahan atau bagian krisisnya, siswa mulai sedikit bersemangat, ditambah lagi dengan membebaskan untuk mengerjakan secaraber pasangan. Suasana yang diciptakan oleh guru juga sangat bersahabat dan santai, sehingga siswa tidak merasa terbebani dengan kondisi yang kaku.

Pada siklus I nilai rata-rata hasil tes siswa didapat nilai sebesar 68,53 dan pada siklus I terdapat 19 sisw yang mendapatkan nilai di atas KKM dari 30 siswa. Sedengkan jumlah siswa yang mendapatkan nilai masih di bawah KKM adalah sebanyak 11 siswa dari 30 siswa yang mengikuti tes. Hal ini jelas belum memenuhi target dari yang ingin di capai peneliti. Dengan hasil tes demikian maka di dapatlah persentase nilai diatas $\mathrm{KKM}$ yaitu sebesar $63,33 \%$. Sementara dari uraian yang telah dipaparkan di $\mathrm{BAB}$ terdahulu bahwa peneliti menargetkan penelitian ini mencapai keberhasilan sebesar $80 \%$. Untuk lebih jelasnya ada baiknya kita melihat grafik statistik hasil tes siswa pada siklus I, seperti pada grafik di bawah ini: 


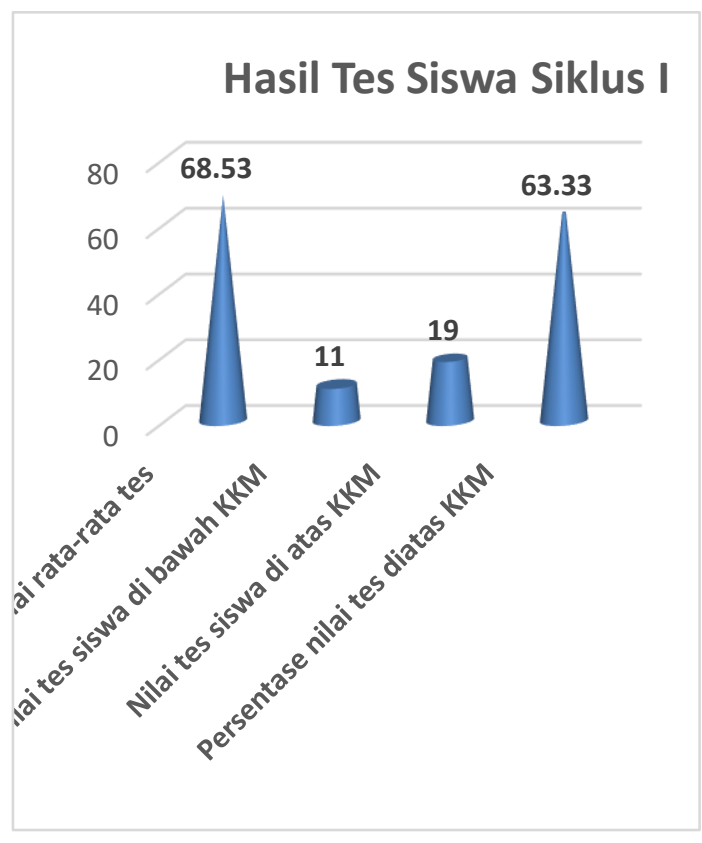

Siklus II

Pada siklus II, tindakan yang diberikan hampir sama dengan tindakan pada siklus I. Dalam siklus II ada beberapa penambahan tindakan sebagai perbaikan tindakan siklus I. Hal tersebut bertujuan agar pembelajaran Sel Elektrokimia lebih optimal, baik dilihat dari proses maupun hasilnya. Pada siklus II, siswa lebih antusias dalam mengikuti pelajaran. Terbukti terjadi peningkatan keasntusiasan siswa yang dibandingkan dalam table berikut:
Tabel Hasil Observasi pada Siklus II

\begin{tabular}{|c|c|c|c|c|c|}
\hline \multirow{2}{*}{$\begin{array}{l}\mathbf{N} \\
\mathbf{O}\end{array}$} & \multirow[t]{2}{*}{ ASPEK } & \multirow[t]{2}{*}{ INDIKATOR } & \multicolumn{3}{|c|}{$\begin{array}{c}\text { PERTEMU } \\
\text { AN KE - }\end{array}$} \\
\hline & & & 1 & 2 & 3 \\
\hline 1 & $\begin{array}{l}\text { Situasi } \\
\text { Belajar }\end{array}$ & $\begin{array}{c}\text { Keantusiasansisw } \\
\text { amengikuti proses } \\
\text { pembelajaran }\end{array}$ & $\begin{array}{l}68 \\
\%\end{array}$ & $\begin{array}{l}70 \\
\%\end{array}$ & $\begin{array}{l}75 \\
\%\end{array}$ \\
\hline 2 & $\begin{array}{l}\text { Perhatia } \\
\text { n/Fokus }\end{array}$ & $\begin{array}{c}\text { Perhatiansiswater } \\
\text { hadappenjelasan } \\
\text { guru saat proses } \\
\text { pembelajaran }\end{array}$ & $\begin{array}{l}65 \\
\%\end{array}$ & $\begin{array}{l}70 \\
\%\end{array}$ & $\begin{array}{l}80 \\
\%\end{array}$ \\
\hline 3 & $\begin{array}{c}\text { Keaktifa } \\
n\end{array}$ & $\begin{array}{c}\text { Peransiswadalam } \\
\text { proses } \\
\text { pembelajaran } \\
\end{array}$ & $\begin{array}{l}60 \\
\%\end{array}$ & $\begin{array}{l}70 \\
\%\end{array}$ & $\begin{array}{l}75 \\
\%\end{array}$ \\
\hline 4 & $\begin{array}{l}\text { Proses } \\
\text { Belajar }\end{array}$ & $\begin{array}{l}\text { Susasana proses } \\
\text { pembelajaran di } \\
\text { kelas }\end{array}$ & $\begin{array}{l}65 \\
\%\end{array}$ & $\begin{array}{l}70 \\
\%\end{array}$ & $\begin{array}{l}80 \\
\%\end{array}$ \\
\hline
\end{tabular}

\begin{tabular}{|c|c|}
\hline & \\
\hline BS & : BaikSekali (76\%-100\% \\
\hline & : Baik (51\%-75\%) \\
\hline & : Cukup (26\%-50\%) \\
\hline & : Kurang (0\%-25\%) \\
\hline
\end{tabular}

Suasana belajar mengajar tergolong dalam kualifikasi baik yaitu $74 \%$. Siswa sudah sadar terhadap kewajibannya dan tidak lebih mudah diarahkan di banding sebelumnya. Selain itu perhatian siswa terhadap penjelasan terhadap Suasana belajar mengajar tergolong dalam kualifikasi baik yaitu 74\%. Siswa sudah sadar terhadap kewajibannya dan tidak lebih mudah diarahkan di bandings belumnya. Selainitu perhatian siswa terhadap penjelasan terhadap guru terjadi peningkatan dari $68 \%$ pada pertemuan pertama meningkat $4 \%$ menjadi $72 \%$ pada pertemuanketiga. 
Siswa lebih aktifdalam kegiatan belajar mengajar terbukti terjadi peningkatan $10 \%$ dari siklus II pertemuan 1 kesiklus II pertemuan 3. Hal inimasuk dalam kualifikasi baik. Proses belajar mengajart ak kalahmeningkat sebesar 7\%, selisih antara siklus II pertemuan 3 dan siklus II pertemuan 1. Terlihat siswa sudah sadar dengan tugasnya masing-masing. Tidak ada siswa yang jalan-jalan atau mengganggu kelompok lain. Siswa berkonsentrasi dalam pelajaran dan memanfaatkan waktu dengan sebaikbaiknya.

Pada siklus II nilai rata-rata hasil tes siswa didapat nilai sebesar 81,17 dan pada siklus II terdapat 26 sisw yang mendapatkan nilai di atas KKM dari 30 siswa. Sedengkan jumlah siswa yang mendapatkan nilai masih di bawah KKM adalah sebanyak 4 siswa dari 30 siswa yang mengikuti tes. Hal ini jelas belum memenuhi target dari yang ingin di capai peneliti. Dengan hasil tes demikian maka di dapatlah persentase nilai diatas KKM yaitu sebesar 86,67 \%. Sementara dari uraian yang telah dipaparkan di $\mathrm{BAB}$ terdahulu bahwa peneliti menargetkan penelitian ini mencapai keberhasilan sebesar $80 \%$.Untuk lebih jelasnya ada baiknya kita melihat grafik statistik hasil tes siswa pada siklus I, seperti pada grafik di bawah ini:

\section{Hasil Tes Siswa Siklus II}

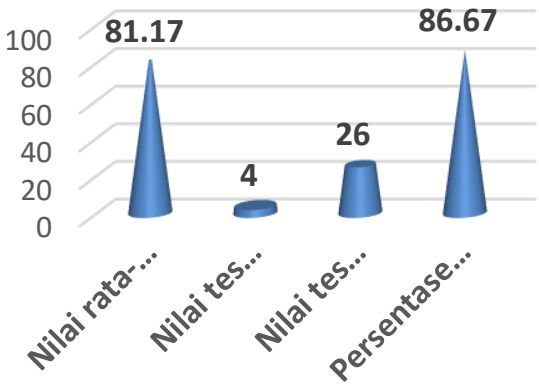

\section{Pembahasan}

Pembahasan hasil penelitian ini meliputi (1) informasi awal dan pengalaman siswa dalam proses belajar pada materi Sel Elektrokimia (pratindakan), (2) pelaksanaan tindakan kelas Sel Elektrokimia dengan strategi Konstruktivisme, dan (3) peningkatan keterampilan menyelesaikan lsoal-soal Sel Elektrokimia dengan strategi Konstruktivisme.

\section{SIMPULAN}

Pembelajaran dengan strategi Konstruktivisme, dapat meningkatkan hasil kemampuan Sel Elektrokimia. Hal ini terlihat dari skor 
rata-rata sebelum diberi tindakan adalah 64,53, setelah di beri tindakan pada akhir siklus I skor rata-rata menjadi 68,53. Skor rata-rata pada akhir siklus II yaitu 81,17. Hal tersebut menunjukkan adanya peningkatan sebesar 12,64 poin. Secara keseluruhan pada akhir siklus II ini semua aspek dan kriteriaSel Elektro kimia mengalami peningkatan yang cukup signifikan. Dari hasil penelitian di atas terbukti bahwa penggunaans trategi Konstruktivisme dinilai berhasil dan dapat meningkatkan kemampuan Sel Elektrokimia siswa kelas XII IPA 1 SMA Negeri 1 Kayuagung.

Berdasarkan kesimpulan dan hasil penelitian di atas, saran yang dapat dikemukakan adalah sebagai berikut: Bagi siswa, hendaknya selalu memperhatikan apa yang disampaikan oleh guru. Siswa yang suda hmendapatkan hasil baik harus dipertahankan bahkan harus ditingkatkan. Bagi siswa yang belum memperoleh hasil baik, jangan pernah patah semangat, terus berlatih agar dapat meningkat. Bagi guru Kimia, disaran kanuntuk menggunakan strategi Konstruktivisme dalam pembelajaran Sel Elektrokimia agar pembelajaran lebih menarik, inovatif, menyenangkan, dan tidak membosankan. Berusaha memperhatikan dan memahami setiap kesulitan belajar siswa kemudian dicari solusi dan pemecahannya. Guru hendaknya selaluk reatif dan inovatif dalam pelaksanaan proses pembelajaran khususnya pembelajaran Sel Elektrokimia.

\section{DAFTAR PUSTAKA}

Asmani, Jamal Ma'mur. 2011. Buku Panduan Internalisasi

Pendidikan Karakter di Sekolah. DIVA Press: Yogyakarta

Dharma Kesuma. 2012. Pendidikan Karakter Kajian Teori dan Praktik di

Sekolah. Bandung: PT Remaja Rosdakarya

Djamarah, Syaiful Bahri. 2012. Psikologi Belajar. Jakarta : Rineka Cipta.

Hamalik, Oemar. 2008. Proses Belajar Mengajar. Jakarta: Bumi Aksara.

Hamdani. 2011. Strategi Belajar Mengajar. Bandung: CV Pustaka Setia. 
Usinawati,Meningkatkan Prestasi Belajar...

Pardjonodkk. 2007. Panduan

PenelitianTindakan Kelas.

Yogyakarta: Lembaga

PenelitianUniversitas Negeri

Yogyakarta.

Sardiman. 2011. Interaksi dan Motivasi Belajar Mengajar. Jakarta: PT. Raja Grafindo Persada.

Slameto. (2013). Belajar dan FaktorFaktor yang Mempengaruhi. Jakarta: Rineka Cipta

Slameto. 2003. Belajar dan Faktor-

Faktor yang

Mempengaruhinya. Jakarta: PT

Rineka Cipta.

Sudjana, N. (2010). Penilaian Hasil

Proses Belajar Mengajar.

Bandung: PT. Remaja

Rosdakarya.

Sutama, 2000. Peningkatan Efektifitas

Pembelajaran Matematika

Melalui Pembenahan Gaya

Mengajar di SLTP N 18

Surakarta. Yogyakarta:

Program Pasca Sarjana UNY.

(tidak diterbitkan)

Winkel, W. S. 2004. Psikologi

Pendidikan dan Evaluasi

Belajar. Jakarta: PT. Gramedia

Pustaka Utama. 